\title{
Efektywność funkcjonalnej Rytmiczno-Ruchowej Rehabilitacji Głosu w terapii wokalisty z zaburzeniami gtosu
}

\section{The effectiveness of functional Rhythm and Movement Voice Rehabilitation in therapy the singer with voice disorders}

\author{
Ewa Kazanecka ${ }^{1}$, Agata Wrońska $^{1}$, Agata Szkiełkowska ${ }^{1,2}$ \\ ${ }^{1}$ Uniwersytet Muzyczny Fryderyka Chopina, Wydział Wokalno-Aktorski, Katedra Audiologii i Foniatrii, \\ Warszawa \\ ${ }^{2}$ Instytut Fizjologii i Patologii Słuchu, Światowe Centrum Słuchu, Warszawa/Kajetany
}

Adres autora: Ewa Kazanecka, Uniwersytet Muzyczny Fryderyka Chopina, Katedra Audiologii i Foniatrii, ul. Okólnik 2, 00-368 Warszawa, e-mail: ewkazanecka@gmail.com

\section{Streszczenie}

Cel pracy: Celem pracy jest przedstawienie autorskiego programu funkcjonalnej Rytmiczno-Ruchowej Rehabilitacji Głosu oraz efektów terapii przeprowadzonej u wokalisty z zaburzeniami głosu.

Materiał i metody: 22-letni wokalista rozrywkowy z zaburzeniami głosu w mowie i śpiewie był leczony funkcjonalną metodą opracowaną przez pedagoga śpiewu i foniatrę w Katedrze Audiologii i Foniatrii UMFC. Wynik terapii oceniany był za pomocą wywiadu, VHI, odsłuchowej i fizykalnej oceny percepcyjnej, badania wideostroboskopowego i akustycznego, wykonanych przed terapią i 3 lata po rozpoczęciu terapii.

Wyniki: Badania wykonane 3 lata od momentu rozpoczęcia terapii wykazały ustąpienie dolegliwości, redukcję punktów VHI, poprawę w ocenie funkcjonalnej oraz parametrach akustycznych i wibracji fałdów głosowych.

Wnioski: Rytmiczno-Ruchowa Rehabilitacja Głosu może być skuteczna w terapii i profilaktyce zaburzeń głosu wokalisty.

Słowa kluczowe: afonia $\bullet$ rehabilitacja $\bullet$ zaburzenia głosu

Abstract

Aim: The aim of the paper is to present the original programme of the functional Rhythm and Movement Voice Rehabilitation, as well as the effects of therapy of a singer with voice disorders.

Material and method: The 22 year-old singer performing popular music who presented voice disorders in speech and singing was underwent the treatment with the application of the functional therapy. Specifically, a method developed by a phoniatrist and a singer in the Chair of Audiology and Phoniatrics UMFC was used. The outcome of therapy was assessed by the auditorial and physical perceptual judgment, a videostroboscopic examination, the acoustic measurements before and 3 years after the therapy. Such assessment was performed before the treatment and 3 years after the treatment.

Results: The study made three years from the start of therapy showed regression of symptoms, reduction in points VHI, as well as the improvement in perceptual assessment, parameters of the acoustic and vibrations of the vocal folds.

Conclusion: The Rhythm and Movement Voice Rehabilitation may be useful in the treatment and prevention of vocal disorders in the singer.

Key words: aphonia $\bullet$ rehabilitation $\bullet$ voice disorders 


\section{Wstęp}

Przeciążanie narządu głosu niewłaściwymi nawykami czynnościowymi jest istotnym czynnikiem etiologicznym dysfonii u osób zawodowo posługujących się głosem. W połączeniu z obciążeniami wynikającymi z czasu i specyfiki używania głosu oraz czynnikami emocjonalnymi i zdrowotnymi $[1,2]$ może dojść do upośledzenia funkcji głosowej, które utrudni wykonywanie zawodu. Zaburzenie głosu wynikające $\mathrm{z}$ niewłaściwego jego używania i negatywnych nawyków jest klasyfikowane jako dysfonia behawioralna lub czynnościowa. W takich wypadkach leczenie farmakologiczne i fizykoterapia usuwają jedynie skutki przeciążania krtani, dając chwilową poprawę. Pacjent wraca do dawnego trybu życia oraz starych nawyków i problem głosowy ponawia się. Przyczynowym leczeniem powyższych przypadków jest rehabilitacja funkcjonalna. Jednak ta forma terapii wymaga od pacjenta zaangażowania, a efekty zauważalne są po dłuższym okresie systematycznej pracy nad sobą. Programy rehabilitacyjne trwają przynajmniej 4-6 miesięcy i oprócz samodzielnej pracy pacjenta wymagają co najmniej 8-10 sesji z trenerem [3-6].

W rehabilitacji głosu widoczne są różne podejścia metodologiczne, niemniej wszystkie mówią o konieczności świadomego wprowadzenia zmian w życie pacjenta. Stemple [7] wyróżnia trzy kierunki rehabilitacji: higienę głosu, podejście objawowe i fizjologiczne. Celem higieny głosu jest wykrycie i wyeliminowanie negatywnych nawyków sprzyjających rozwojowi zaburzeń głosu takich jak nadużywanie głosu, częste rozmowy w hałaśliwym otoczeniu, brak snu, aktywności fizycznej, palenie papierosów, niedostateczne nawodnienie czy niewłaściwa dieta [8]. Drugi kierunek modyfikuje nieprawidłowe objawy głosowe takie jak twardy atak, przydech, niewłaściwa wysokość i głośność głosu używana w mowie [9]. W podejściu fizjologicznym, holistycznym praca polega na modyfikacji mechanizmu produkcji głosu i obejmuje wszystkie jego podsystemy. Przywracana jest kontrola i równowaga pomiędzy oddychaniem, napięciem mięśni krtani i nagłośniowymi modyfikacjami tonu krtaniowego (rezonansem). Do metod holistycznych Stemple zalicza Metodę Akcentów, Ćwiczenia Funkcji Głosowej (ang. Vocal Function Exercise, VFE), Kompleksowy Program Rehabilitacji Głosu (ang. Comprehensive Voice Rehabilitation Program, CVRP), Terapię Rezonansową Głosu (ang. Resonant Voice Therapy, RVT), Terapię Głosu Lee Silvermana (ang. Lee Silverman Voice Terapy, LSVT), Technikę Manualnej Krtaniowej Mięśniowoszkieletowej Redukcji (ang. Manual Laryngeal Musculosceletal Reduction Technique). Najlepsze efekty daje połączenie tych wszystkich podejść, które Stemple określił jako styl eklektyczny. Programy rehabilitacyjne różnią się materiałem tekstowym ćwiczeń głosowych oraz instrukcjami wykonawczymi. Jedne koncentrują się bardziej na czynnościach oddechowych, inne na odczuciu rezonansu, a jeszcze inne włączają masaż szyi do przywrócenia równowagi mięśni krtani.

Niewiele jest prac dotyczących rehabilitacji głosu wśród śpiewaków. Sabol [10] uzyskała znaczący wzrost parametrów aerodynamicznych, takich jak szybkość przepływu powietrza, objętość fonacyjna, maksymalny czas fonacji MPT, w grupie zdrowych śpiewaków po 4-tygodniowym programie VFE. Tay [11] badała efekty terapeutyczne
VFE w grupie 22 chórzystów mających 65 i więcej lat. Po 5 tygodniach systematycznych ćwiczeń uzyskała poprawę w odczuciu szorstkości, parametrach akustycznych (Jitter, Shimmer, NHR) oraz wydłużenie maksymalnego czasu fonacji MPT.

Śpiewacy to grupa zawodowa, która od początku pracuje nad doskonaleniem techniki głosowej. Niemniej pedagodzy nie zawsze radzą sobie z problemami głosowymi swoich uczniów, nawet tymi o podłożu czynnościowym. Zaburzenia głosu mogą występować u nich w mowie i śpiewie lub tylko w śpiewie. Ośrodek foniatryczny, do którego zgłaszają się wokaliści szukający pomocy, powinien mieć program terapeutyczny poprawiający obie funkcje głosowe.

Celem pracy jest przedstawienie zasad rehabilitacji głosu oraz efektów terapii zaburzeń głosu u wokalisty, przeprowadzonej z wykorzystaniem autorskiego programu funkcjonalnej Rytmiczno-Ruchowej Rehabilitacji Głosu, wypracowanego wspólnie przez pedagoga śpiewu i foniatrę w Katedrze Audiologii i Foniatrii UMFC.

\section{Material i metody}

W pracy przedstawione są efekty terapii wokalisty rozrywkowego (MR, lat 25), który z powodu zaburzeń głosu zrezygnował ze studiów wokalnych w Akademii Muzycznej oraz wykonywania zawodu. Pacjent w momencie rozpoczęcia terapii miał 22 lata. Zgłosił się do IFPS z nasilającymi się od 2 lat problemami głosowymi w mowie i śpiewie. Była to chrypka, matowość, niestabilność głosu, zawężona skala głosu, mała tolerancja wysiłków głosowych, np. półgodzinna rozmowa telefoniczna nasilała dolegliwości. Objawom głosowym towarzyszyło uczucie suchości, pieczenia, „ciała obcego” w gardle oraz duży lęk przed niedyspozycją głosu. Po przeprowadzeniu pełnej diagnostyki, leczeniu farmakologicznym i fizykoterapii pacjent został skierowany do Katedry Audiologii i Foniatrii UMFC w celu rehabilitacji funkcjonalnej. Terapia przeprowadzana była przez drugiego autora, z wykształcenia wokalistę, mającego wieloletnie doświadczenie w nauczaniu śpiewu i rehabilitacji głosu. W prezentowanym przypadku pacjent pracował $\mathrm{z}$ terapeutą jedną godzinę tygodniowo przez 10 miesięcy. Zanim wprowadzono zadania wokalne, 10 sesji poświęcono na naukę podstawowych czynności emisyjnych.

Ocena efektów rehabilitacji polegała na porównaniu wyników badań wykonanych przed terapią i trzy lata po jej rozpoczęciu. Procedura diagnostyczna obejmowała wykorzystanie następujących technik i narzędzi: 1) wywiad, 2) samoocena głosu dokonana przez pacjenta za pomocą ankiety Indeks Niepełnosprawności Głosu VHI, 3) badanie laryngologiczno-foniatryczne z wideostroboskopią krtani, 4) test wokalny, polegający na subiektywnej ocenie jakości i zakresu głosu wykorzystywanego w mowie i śpiewie oraz czynności tworzenia i emisji głosu, 5) wieloparametryczną analizę akustyczną głosu MDVP.

\section{Program terapii w ramach Rytmiczno-Ruchowej Rehabilitacji Głosu}

Istotą metody jest rozwijanie świadomości ciała, aby pacjent samodzielnie oceniał, a później kontrolował stan 
aktywności mięśni oddechowych i artykulacyjnych. Celem pracy jest uzyskanie swobodnego ruchu żeber, miednicy, żuchwy oraz umiejętności kontrolowania przepływu powietrza w drogach oddechowych, zależnie od zadania głosowego. Integralną częścią terapii jest trening słuchowy. W rehabilitacji głosu śpiewaka można wyróżnić dwa etapy. Pierwszy etap polega na kształtowaniu podstawowych czynności tworzenia i emisji głosu, drugi to nauka wykorzystywania ukształtowanych wcześniej czynności emisyjnych w śpiewie. Czas trwania całej terapii oraz poszczególnych jej etapów dobierany jest indywidualnie, zależnie od oczekiwań i postępów pracy z daną osobą.

W ćwiczeniach pierwszego etapu pacjent obserwuje swoje ciało i głos. Poznaje odczucia towarzyszące rytmicznym ruchom przemieszczania miednicy do przodu i tyłu, opuszczania i unoszenia żuchwy, przemieszczania przedniej ściany brzucha do wewnątrz i z powrotem. Pacjent obserwuje oddychanie nie tylko przez ruchy oddechowe tułowia, lecz także poprzez odczucia związane z przepływem powietrza w jamie nosowej i ustnej. Ruchy ciała, fazy oddechowe i akcenty głosowe porządkowane są schematami rytmicznymi. Podstawą konstrukcyjną ćwiczeń jest 3-fazowy cykl oddechowy: pauza oddechowa - wdech - wydech. Rozpoczęcie i zakończenie wdechu oraz wydechu powinny być łagodne. W czasie wydechu pacjent wykonuje ruch miednicą do tyłu, a w czasie wdechu do przodu. W każdym cyklu stosunkowo dużo czasu zajmuje pauza oddechowa, poświęcana na rozluźnienie mięśni oddechowych i artykulacyjnych. Rozluźnienie powyższych mięśni widoczne jest jako niewielkie przesunięcie przedniej ściany brzucha do przodu, swobodne opadnięcie żuchwy i wypełnienie całego dna jamy ustnej językiem. Ma to ułatwić wykonanie w krótkim czasie wdechu, podczas którego powietrze przepływa przez jamę nosową i ustną, po czym rozpoczęcie zadania głosowego z rozluźnionymi artykulatorami. Wydech, zależnie od zadania, połączony jest lub nie z tworzeniem głosu. Pacjent powinien koncentrować się na odczuciach towarzyszących przepływowi powietrza oraz rozluźniania mięśni tułowia, języka i żuchwy z chwilą kończenia tworzenia głosu. Pierwsze ćwiczenia, polegające na utrzymaniu jednostajnego przepływu powietrza w drogach oddechowych, wykonywane są na spółgłoskach bezdźwięcznych szczelinowych [s], [sz], [f], a następnie ich dźwięcznych artykulacyjnych odpowiednikach [z], [ż], [w]. W dalszej kolejności praca odbywa się na sylabach, przy czym jako pierwsze wprowadzane są spółgłoski przedniojęzykowe, a później tylnojęzykowe. Następne zadania polegają na różnicowaniu wielkości przepływu powietrza. Podczas fonowania ciągłych samogłosek pacjent, zależnie od ćwiczenia, wykonuje od 1 do 3 akcentów mięśniami przedniej ściany brzucha. Naprzemiennie przemieszcza ją nieznacznie do wewnątrz jamy brzusznej i rozluźnia mięśnie, starając się ograniczyć ruch jedynie do okolicy podbrzusza. Cały czas musi być zachowany przepływ powietrza. W ten sposób uzyskiwane są zmiany głośności. Na tym etapie głos utrzymywany jest na najwygodniejszym dla pacjenta poziomie wysokości. Kolejne zadania polegają na wymawianiu wyrazów i prostych fraz. Terapeuta pokazuje, jak wykorzystywać czynności do uzyskania zmian głosu, by za pomocą odpowiednich cech prozodycznych wyrazić konkretną intencję i emocję.

Zadania głosowe pacjent wykonuje na zmianę z trenerem podczas sesji terapeutycznych oraz w domu, wykorzystując nagrany przez trenera na CD materiał ćwiczeniowy, stanowiący kontynuację sesji. W ten sposób pacjent cały czas ma wzorzec poprawnej realizacji zadania i odruchowo wykonuje ćwiczenie, wykorzystując naśladownictwo.

Drugi etap pracy metodą Rytmiczno-Ruchowej Rehabilitacji Głosu związany jest z wykorzystywaniem ukształtowanych wcześniej czynności emisyjnych w śpiewie. Zadania śpiewane początkowo ograniczane są do zakresu dźwięków mowy i krótkich fraz, ale z narzucaną wysokością i głośnością. Pacjent wykonuje je z towarzyszeniem instrumentu muzycznego. Punktem wyjściowym i kończącym ciąg zadań wokalnych jest wygodna wysokość głosu danej osoby. Wykorzystywany jest materiał tekstowy wcześniejszych ćwiczeń. Zadania konstruowane są w ten sposób, by podobnie jak w pierwszym etapie pacjent pracował nad łagodnym rozpoczynaniem dźwięku oraz rozluźnianiem mięśni oddechowych i artykulacyjnych z chwilą kończenia śpiewania. W ćwiczeniu wokalnym stosuje się dużo pauz akustycznych, a także nadal przeznacza się dużo czasu na rozluźnienie mięśni przed kolejnym wdechem. Wspólnie $\mathrm{z}$ terapeutą pacjent uczy się dozować przepływ powietrza, by dostosować jego wielkość do przebiegu frazy.

Zadanie głosowe drugiego etapu polega na przykład na śpiewaniu fraz złożonych $\mathrm{z}$ oddzielanych, równych metrycznie 2-3 dźwięków różniących się wysokością. Pierwszy jest dźwiękiem o wygodnej wysokości, z poziomu średniego położenia w mowie. Stopniowo zwiększany jest zakres wysokości pomiędzy dźwiękami. W dalszej kolejności śpiewane są frazy złożone z 2-3 dźwięków o sekundowej różnicy wysokości, przemieszczając się od wygodnego dźwięku w górę skali (ograniczając się do wygodnej jej części), następnie w dół skali i na koniec powrót do dźwięku wygodnego. Dopiero kiedy pacjent radzi sobie z czynnościami w powyższych zadaniach, wprowadzane jest do ćwiczeń legato.

Podobnie jak w przypadku mowy w pierwszym etapie terapeuta pomaga pacjentowi przenieść kształcone czynności do zaawansowanych zadań wokalnych i utworów, w których zmiany głosu dyktowane są przez zapis nutowy oraz specyfikę wykonywanego stylu muzycznego.

\section{Wyniki}

Za pomocą testów diagnostycznych przeprowadzonych przed terapią funkcjonalną, oprócz zgłaszanych przez pacjenta dolegliwości, stwierdzono średniego stopnia niepełnosprawność narządu głosu. W obrazie endoskopowym krtani uwidoczniono wzmożony rysunek naczyniowy na powierzchni fałdów głosowych, cechy obrzęku podnabłonkowego wzdłuż całej długości fałdów głosowych na ich górnej powierzchni i środowej części wolnego brzegu, niepełne domknięcie głośni w jej przedniej i tylnej części, zaleganie śluzu oraz lekkie przywodzenie fałdów przedsionkowych, zwłaszcza w przedniej części głośni. W badaniu wideostroboskopowym drgania fałdów głosowych były synchroniczne, symetryczne, o zmniejszonej amplitudzie, w otwartej części cyklu szpara głośni przyjmowała trójkątny kształt, z maksymalnym przemieszczeniem fałdów w ich tylnej części (rycina 1A-C). Maksymalny czas fonacji był skrócony do 17 sekund. W wieloparametrycznej analizie akustycznej próbki głosu nagranej podczas fonacji ciągłej głoski [a] 


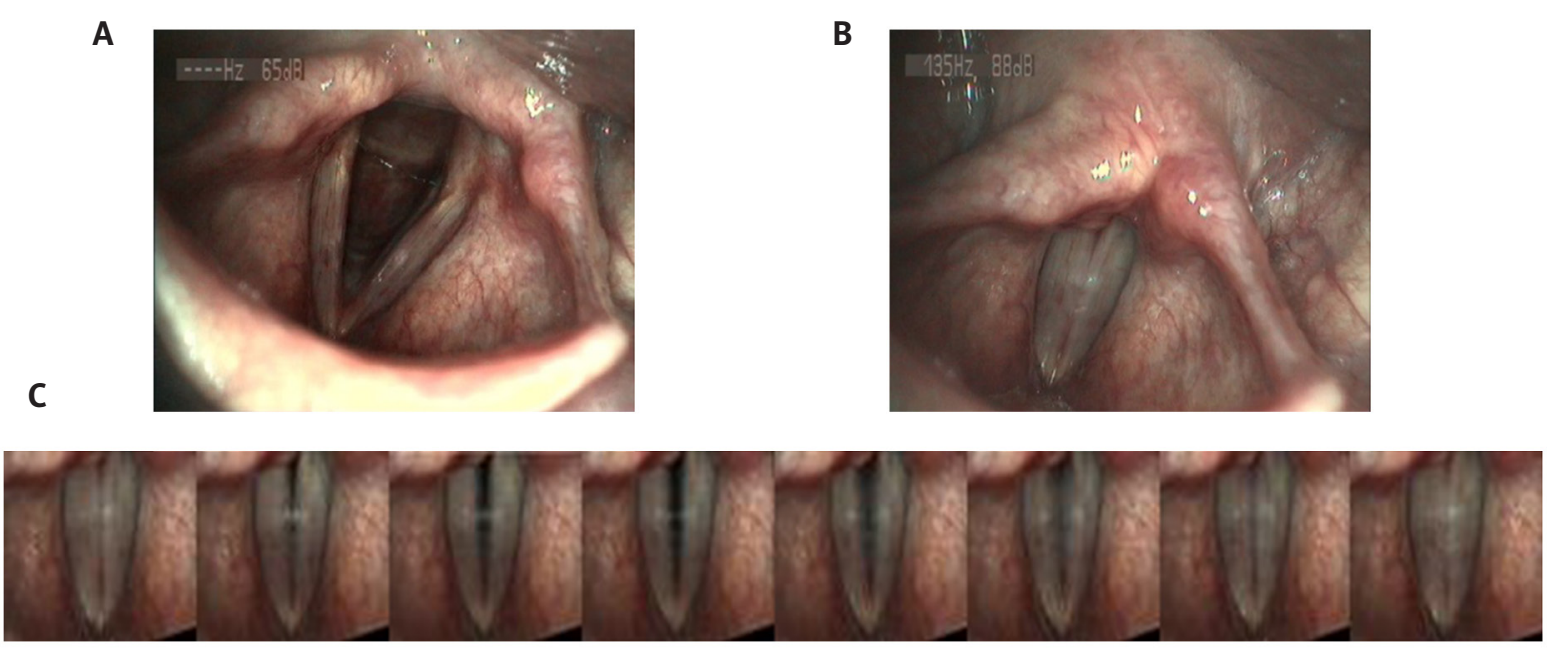

Rycina 1. Badanie endoskopowe krtani przed rehabilitacją: (A) fałdy głosowe podczas oddychania; (B) fałdy głosowe podczas fonacji; (C) montaż 1 cyklu wibracyjnego fałdów głosowych uzyskany z wideostroboskopii

Figure 1. Enodoscopic examination of larynx before rehabilitation: (A) vocal folds during breathing; (B) vocal folds during phonation; (C) montage of 1 vibratory cycle of vocal folds obtained from videostroboscopy

A

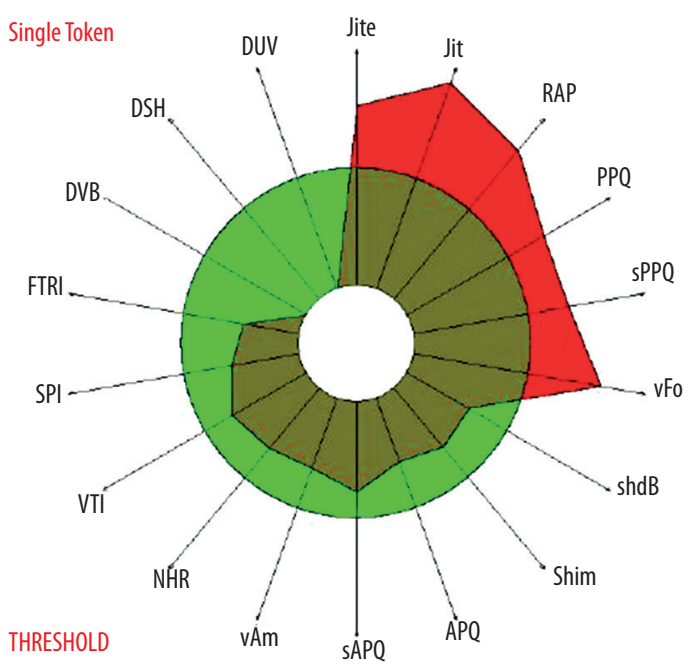

B

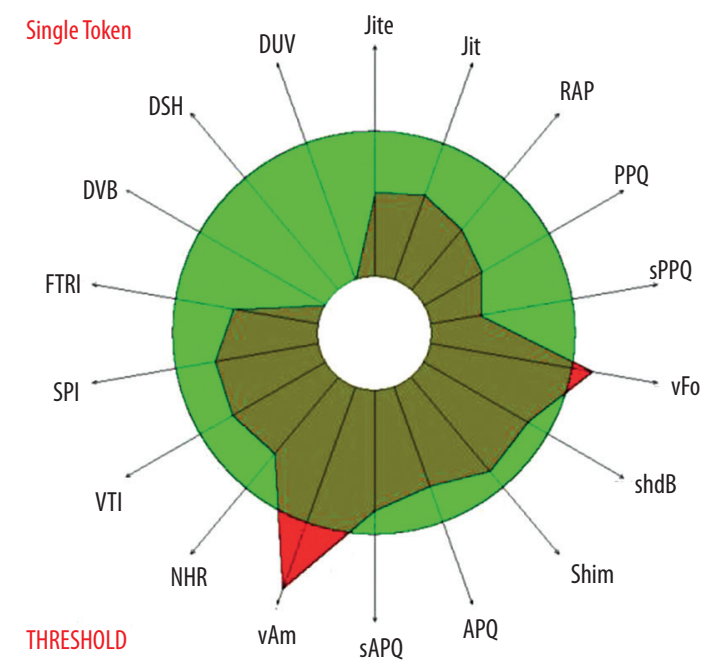

Rycina 2. Analiza MDVP: (A) przed rehabilitacją (przekroczone parametry: Jite, Jit, RAP, PPQ, sPPG, vF0), (B) po rehabilitacji (niewielkie przekroczenie parametru $v$ Am i vFO)

Figure 2. Analysis MDVP: (A) before rehabilitation, (B) after rehabilitation

uzyskano zaburzenie krótkoterminowych i długoterminowych parametrów związanych z częstotliwością (Jite, Jit, RAP, PPQ, sPPQ, vF0) (rycina 2A). Taki wynik wskazuje na zaburzenie mechanizmu tworzenia głosu na poziomie generatora. Terapeuta $\mathrm{w}$ teście wokalnym stwierdził zawężenie skali głosu śpiewaczego, różnego typu zaburzenia głosu występujące w przypadkowy sposób na różnych dźwiękach, zależnie od sposobu wydobycia głosu, oraz szereg niekorzystnych czynności emisyjnych dotyczących oddychania, artykulacji, pozycji krtani, jak również twarde ataki głosu. W tabeli 1. przedstawiono porównanie wyników testów diagnostycznych przeprowadzonych przed terapią funkcjonalną i po 3 latach od momentu jej rozpoczęcia.

W efekcie terapii głosu ustąpiły zgłaszane przez pacjenta dolegliwości i zaburzenia głosu, zwiększyła się tolerancja wysiłków głosowych oraz ustąpił lęk przed niedyspozycją głosu. Po roku rehabilitacji pacjent wrócił do zawodu, stopniowo zwiększając wysiłki. Aktualne pracuje głosem około 3 godziny dziennie, nagrywając w studiu piosenki, śpiewa jeden koncert w miesiącu, poprzedzany kilkoma 4-godzinowymi próbami oraz pracuje jako aktor, 1-2 razy w miesiącu uczestnicząc $w$ trzydniowych zdjęciach filmowych. Liczba punktów uzyskanych w ankiecie VHI uległa zmniejszeniu z 35 do 4. Pacjent poprawił technikę tworzenia i emisji głosu, poszerzył skalę głosu śpiewaczego. Maksymalny czas fonacji wydłużył się do 20 sekund.

W obrazie endoskopowym wykonanym 3 lata od momentu rozpoczęcia terapii stwierdzono cofnięcie następstw przeciążania krtani, brzegi fałdów głosowych są gładkie i nie stwierdza się aktywności okolic nagłośniowych. 
Tabela 1. Porównanie wyników badań wykonanych przed rehabilitacją i 3 lata po rehabilitacji głosu Table 1. Comparison results of tests carried out before and 3 years after the rehabilitation of voice

\begin{tabular}{|c|c|c|}
\hline Badanie & Rok 2013 & Rok 2016 \\
\hline Wywiad & $\begin{array}{l}\text { Chrypka, matowość głosu, niestabilność, zawężona } \\
\text { skala głosu, mała tolerancja wysiłków głosowych, } \\
\text { np. półgodzinna rozmowa telefoniczna nasilała } \\
\text { dolegliwości, z towarzyszącym uczuciem suchości, } \\
\text { pieczenia i uczuciem „kluski” w gardle. Duży lęk } \\
\text { o dyspozycję głosu. }\end{array}$ & $\begin{array}{l}\text { Nie zgłasza zaburzeń głosu, wrócił do zawodu, ustąpił } \\
\text { lęk o dyspozycje głosu. Aktualne wysiłki to: nagrania } \\
\text { piosenek około } 3 \text { godz./dzień, próby do koncertów } \\
4 \text { godz., koncerty 1/miesiąc; pracuje jako aktor } \\
\text { - 3-dniowe zdjęcia filmowe } 1-2 \times \text { /miesiąc). }\end{array}$ \\
\hline $\mathrm{VHI}$ & $\mathrm{VHI}=35$ p $(\mid=7 ;\|-11 ;\| I=17)$ & $\mathrm{VHI}=4 \mathrm{p}(\mathrm{I}=0 ;\|=1 ;\| I=3)$ \\
\hline $\begin{array}{l}\text { Wideoendo- } \\
\text { stroboskopia }\end{array}$ & $\begin{array}{l}\text { Suchość błon śluzowych, cechy LPR, cechy przeciążenia } \\
\text { FG (wzmożony rysunek naczyniowy, obrzęk lewego FG) } \\
\text { drgania fonacyjne regularne, synchroniczne, amplituda } \\
\text { największa w tylnej części fałdów głosowych, w czasie } \\
\text { fonacji szczelina głośni w kształcie klepsydry, małego } \\
\text { stopnia kompresja FVF przedsionka krtani. }\end{array}$ & $\begin{array}{l}\text { Fałdy głosowe białe, brzeg gładki; drgania fonacyjne } \\
\text { regularne, symetryczne, synchroniczne, amplituda } \\
\text { prawidłowa największa w środkowej części fałdów } \\
\text { głosowych, przesunięcie brzeżne widoczne, } \\
\text { domknięcie fonacyjne dostateczne. } \\
\text { Fałdy przedsionkowe nie przesłaniają fałdów } \\
\text { głosowych. }\end{array}$ \\
\hline Test wokalny & $\begin{array}{l}\text { Skala głosu: H-d }{ }^{1} \\
\text { Negatywne cechy głosu: matowość, szorstkość, } \\
\text { niestabilność, detonacje, astenicznośc, pojawiały } \\
\text { się w sposób przypadkowy na różnych dźwiękach } \\
\text { w zależności od sposobu wydobycia, który nie był } \\
\text { powtarzalny, kierował się jedynie wyobrażeniem } \\
\text { jakości dźwięku; brak świadomości czynności } \\
\text { emisyjnych. } \\
\text { Niekorzystne czynności emisyjne: tor oddechowy } \\
\text { piersiowy, paradoksalne ruchy wciągania brzucha } \\
\text { na wdechu, brak rozluźniana brzucha po fonacji, } \\
\text { paradoksalne ruchy wypychania brzucha na } \\
\text { akcentach, duże ruchy pionowe krtani, m.in. unoszenie } \\
\text { w prefonacji, napięta ok. podżuchwowa, wysuwanie } \\
\text { żuchwy na samogłoskach; twarde ataki i zakończenia } \\
\text { fonacji. }\end{array}$ & $\begin{array}{l}\text { Skala głosu: E-d² } \\
\text { Głos dobrej jakości w całej skali. Podczas tworzenia } \\
\text { głosu wykorzystuje świadomą kontrolę czynności } \\
\text { i nowe nawyki. } \\
\text { Niekorzystne czynności emisyjne: w górnym rejestrze: } \\
\text { niekontrolowane ruchy pionowe krtani, napięte } \\
\text { mięśnie brzucha, twarde ataki. }\end{array}$ \\
\hline MPT & 17 sekund & 20 sekund \\
\hline MDVP & Jitta-124,9; RAP-1,13; PPQ-1,17; vF0-1,74 & Jitta-48,2; RAP-0,37; PPQ-0,39 vF0-1,24 \\
\hline
\end{tabular}

A

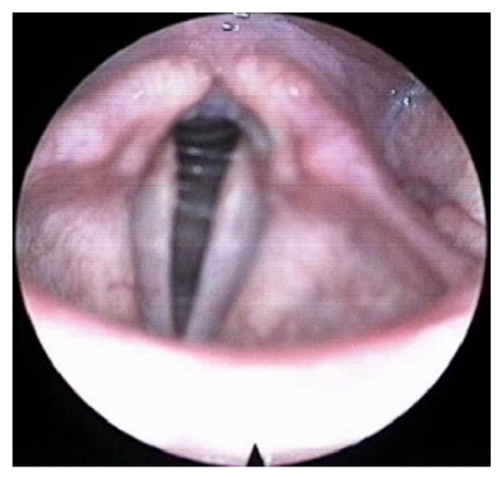

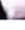

B

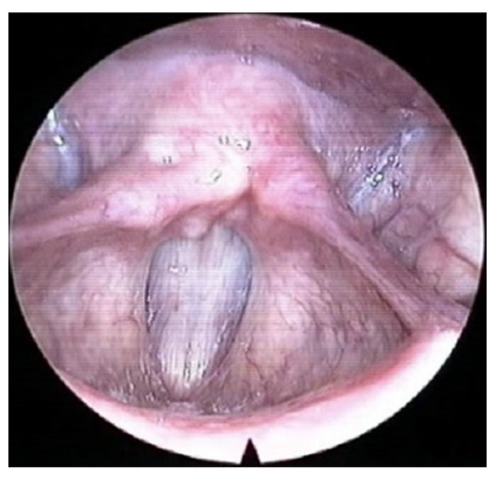

C

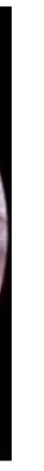

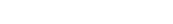

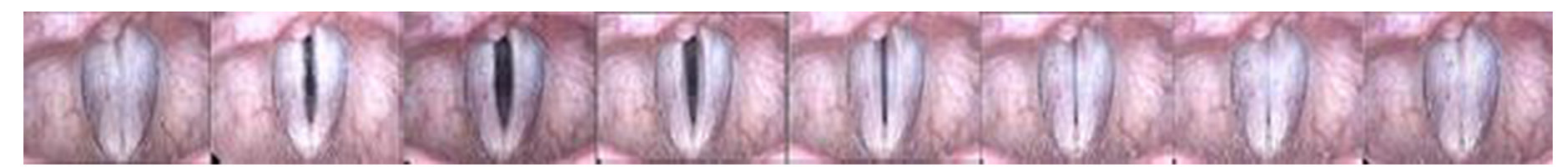

Rycina 3. Badanie endoskopowe krtani po rehabilitacji: (A) fałdy głosowe podczas oddychania; (B) fałdy głosowe podczas fonacji; (C) montaż 1 cyklu wibracyjnego fałdów głosowych uzyskany z wideostroboskopii

Figure 3. Enodoscopic examination of larynx after rehabilitation: (A) vocal folds during breathing; (B) vocal folds during phonation; (C) montage of 1 vibratory cycle of vocal folds obtained from videostroboscopy 
Uległy także poprawie parametry wibracji fałdów głosowych. Domknięcie fonacyjne głośni jest dostateczne na całej długości, zwiększyła się amplituda wibracji, z maksimum w środku międzybłoniastej części fałdów głosowych (rycina $3 \mathrm{~A}-\mathrm{C}$ ).

Aktualne badanie wieloparametrycznej analizy głosu (MDVP) wykazało poprawę jego jakości. Prawie wszystkie parametry są w normie. Stwierdzono tylko niewielkie odchylenie częstotliwości podstawowej vF0 i amplitudy vAm (rycina 2B).

\section{Dyskusja}

Ważnym elementem terapii zaburzeń głosu jest rehabilitacja funkcjonalna, czyli praca nad właściwym mechanizmem jego tworzenia oraz zwiększeniem wydolności narządu głosowego. Ćwiczenia głosowe są główną formą leczenia dysfonii czynnościowych. Rehabilitacja funkcjonalna wykorzystywana jest również jako nieinwazyjna, alternatywna do zabiegów chirurgicznych metoda poprawiająca wydolność głośni w niedowładach fałdów głosowych i presbyfonii $[12,13]$ oraz leczenia zmian obrzękowych błony śluzowej $[14,15]$. Nowoczesne narzędzia obrazowania czynności krtani dają możliwość wykazania korzystnego wpływu ćwiczeń głosowych na poprawę wzorców wibracji fałdów głosowych. Pimenta porównywała analizy kimograficzne, uzyskane $\mathrm{z}$ wideoendoskopii krtani szybkim filmem przed serią kilkuminutowych ćwiczeń i po ich zakończeniu, wibracji warg lub języka w trakcie fonacji [16]. Badania wykazały zwiększenie współczynnika otwarcia i zmniejszenie szybkości zamykania, wskazując na mechanizm sprzyjający łagodnemu kontaktowi fałdów głosowych.

Przedstawiony w artykule autorski program Rytmiczno-Ruchowej Rehabilitacji Głosu, którego skuteczność przedstawiona została na przykładzie wokalisty, skierowany jest do szerokiej grupy odbiorców. W zależności od potrzeb pacjenta można wykorzystać go do terapii zaburzeń głosu zarówno w mowie, jak i śpiewie. Program rehabilitacji składa się z dwóch części. Osoby z problemami głosu mówionego mogą zakończyć pracę na pierwszym etapie. Śpiewacy przechodzą do drugiego etapu, kontynuując terapię na zadaniach wokalnych. W trakcie rehabilitacji pacjent wyposażany jest w narzędzia, które umożliwiają mu dalszą, samodzielną pracę rozwijającą funkcję głosową nawet po zakończeniu terapii.

Skuteczność rehabilitacji głosu wykazywana jest również przez innych autorów, przy czym większość opisywanych programów terapeutycznych dotyczy osób z zaburzeniami głosu mówionego [5,17-23]. Wiele prac przedstawia efekty terapeutyczne programu Vocal Function Exercise (VFE), zaproponowanego przez Stemple [24]. Jest to seria czterech ćwiczeń głosowych, każde wykonywane dwukrotnie, dwa razy dziennie przez kilka tygodni. Roy [21] porównywał efekt terapeutyczny higieny głosu i programu rehabilitacji VFE w dwóch grupach nauczycieli z zaburzeniami głosu. Stwierdził skuteczność obu terapii, z nieco większą poprawą w grupie osób poddanych ćwiczeniom głosowym. Pedrosa [3], w randomizowanych badaniach trzech grup nauczycieli, porównywał efekt terapeutyczny dwóch technik: CVRP (Kompleksowy Program Rehabilitacji Głosu) i VFE w stosunku do osób nieleczonych, stanowiących grupę kontrolną. Obie metody terapeutyczne przyniosły zmniejszenie dolegliwości w porównywalnym stopniu, w przeciwieństwie do braku ustąpienia dolegliwości w grupie osób nieleczonych. VFE skuteczna była również w leczeniu zaburzeń głosu wynikających z atrofii mięśni krtani związanej ze zmianami starczymi [12], w zaburzeniach mutacji [25] oraz u osób z guzkami głosowymi [14].

Powyższe badania obejmują krótki okres obserwacji. Kontrolne badania wykonywane są najczęściej bezpośrednio po zakończeniu kursu terapii, trwającego od 6 do 10 tygodni. $Z$ doświadczenia autorów niniejszej pracy wynika, że jest to zbyt krótki czas, by osiągnąć całkowite wyleczenie, szczególnie w dysfoniach organicznych, w których uszkodzenie błony śluzowej fałdów głosowych jest konsekwencją niewłaściwego mechanizmu fonacji. Pacjent nie zdąży jeszcze wprowadzić nowych, korzystnych nawyków sterujących tworzeniem głosu. Jest to również niewystarczający okres, by móc twierdzić, że rehabilitacja głosu zabezpiecza przed nawrotem dolegliwości. Niemniej, nawet po tak krótkim czasie, możemy zauważyć zmniejszenie dolegliwości pacjenta takich jak wysiłek odczuwany podczas mówienia czy śpiewania, uczucie bólu, napięcia w szyi, suchości i drapania w gardle.

Wyniki 3-letniej obserwacji wokalisty leczonego z wykorzystaniem Rytmiczno-Ruchowej Rehabilitacji Głosu wykazują skuteczność programu. Ustąpiły dolegliwości, pacjent poprawił czynności emisyjne, poszerzył skalę głosu śpiewaczego i wydłużył czas fonacji. Badanie wideostroboskopowe wykazało poprawę parametrów wibracji fałdów głosowych, a analiza akustyczna poprawę jakości głosu.

W proponowanym przez autorów programie rehabilitacji zostało zastosowane podejście fizjologiczne, modyfikujące wszystkie podsystemy mechanizmu tworzenia głosu. Rozwijanie świadomości pozwala pacjentowi kształtować korzystne nawyki czynnościowe w celu uzyskania głosu dobrej jakości. Wokalista zaczyna panować nad swoim głosem i pozbywa się lęku przed jego niedyspozycją. Rozpoczęta podczas terapii praca nad emisją głosu w naturalny sposób zostaje przeniesiona do codziennego życia zawodowego. Ważne jest rozwijanie umiejętności obserwowania przez pacjenta swojego ciała i głosu oraz świadome wykonywanie ćwiczeń, zgodnie ze wzorcem dawanym przez terapeutę. Ćwiczenia oddechowe i głosowe koordynowane są z ćwiczeniami ruchowymi, co pomaga w osiąganiu optymalnego napięcia mięśni tułowia i szyi, angażowanych w tworzeniu głosu. Korzyści wynikające z wykorzystania ruchów ciała i rytmu do uzyskania poprawy kontroli oddechowej opisywane były także przez terapeutów pracujących Metodą Akcentów opracowaną przez Smithsa [22,26-29].

W przedstawianym przez autorów programie rehabilitacji jako jedno z zadań głosowych wykorzystywane jest mormorando. Głos w trakcie tego ćwiczenia tworzony jest przy przymkniętych wargach, neutralnym ukształtowaniu traktu nadgłośniowego i z zachowaniem ciągłego przepływu powietrza. Pacjent uczy się odczuwać wibracje w klatce piersiowej, szyi i twarzy. Ćwiczenia wywodzące się z mormoranda są także podstawą innego programu rehabilitacyjnego, nazwanego Terapią Rezonasową Głosu (RVT). 
Chen wykazywała efektywność tej metody w leczeniu zaburzeń głosu u nauczycieli na podstawie badania stroboskopowego, akustycznego i redukcji wskaźnika VHI [23].

Na konieczność kompleksowego podejścia do terapii zaburzeń głosu wskazują również inni autorzy. Niebudek-Bogusz [5] prezentowała efekty terapeutyczne programu obejmującego ćwiczenia relaksacyjne, oddechowe, głosowe i rezonansowe, przeprowadzonego w grupie ponad 100 nauczycieli z zaburzeniami głosu. Uzyskała zmniejszenie dolegliwości, wydłużenie MPT, poprawę parametrów stroboskopowych oraz poprawę techniki tworzenia głosu.

Przedstawiony program rehabilitacji, oprócz samodzielnej pracy pacjenta, przewiduje także regularne spotkania z terapeutą. Dobrze jest, jeżeli osoba przeprowadzająca rehabilitację głosu śpiewaczego ma wykształcenie muzyczne i umiejętności wokalne. Jest to szczególnie istotne na etapie pracy, kiedy zmiany w mechanizmie tworzenia głosu utrwalane są na złożonych zadaniach wokalnych. Terapeuta-wokalista potrafiący grać na instrumencie akompaniuje pacjentowi w trakcie zadań śpiewanych, utrzymuje ćwiczenie w odpowiednim metrum i tempie oraz uwzględnia specyfikę stylu muzyki wykonywanej przez pacjenta.

\section{Wnioski}

1. Funkcjonalna Rytmiczno-Ruchowa Rehabilitacja Głosu może być skuteczna w terapii i profilaktyce zaburzeń głosu u wokalisty.

2. Rehabilitacja głosu wokalisty wprowadza zmianę w nawykach czynnościowych związanych z tworzeniem głosu; powinna być połączona $\mathrm{z}$ elementami nauki śpiewu, aby proces kształtowania fizjologicznych nawyków był kontynuowany w życiu zawodowym pacjenta.

3. W rehabilitacji głosu wokalisty powinna brać udział osoba $\mathrm{z}$ wykształceniem wokalnym, znająca specyfikę różnych stylów i technik wokalnych, posiadająca umiejętność konstruowania zapisu muzycznego na potrzeby poszczególnych etapów terapii.

4. Rehabilitacja funkcjonalna usuwa istotny czynnik upośledzający funkcję głosową wokalisty, jakim jest lęk przed niedyspozycją głosu.

\section{Piśmiennictwo:}

1. Morrison M. Pattern recognition in muscle misuse voice disorders: how I do it. J Voice, 1997; 11(1): 108-14.

2. Abeida MEU, Liesa RF, Varela HV, Campayo JG. Study of the influence of psychological factors in the etiology of vocal nodules in women. J Voice, 2013; 27(1): 129.e15-e20.

3. Pedrosa V, Pontes A, Pontes P, Behlau M, Peccin SM. The effectiveness of the Comprehensive Voice Rehabilitation Program Compared with the Vocal Function Exercises Method in behavioral dysphonia: A randomized clinical trial. J Voice, 2016; 30(3): 377.e11-19.

4. Harris S. Speech therapy for dysphonia. W: Harris T, Harris S, Rubin J. The voice clinic Handbook. London: Whurr Publishers Ltd., 1998.

5. Niebudek-Bogusz E, Sznurowska-Przygocka B, Fiszer M, Kotyło P, Sinkiewicz A, Modrzewska M, Śliwińska-Kowalska M. The effectiveness of voice therapy for teachers with dysphonia. Folia Phoniatr Logop, 2008; 60(3): 134-41.

6. Szkiełkowska A, Kazanecka E. Emisja głosu wskazówki metodyczne. Warszawa: Instytut Fizjologii i Patologii Słuchu i Uniwersytet Muzyczny Fryderyka Chopina, 2011.

7. Thomas LB, Stemple JC. Voice therapy: Does science support the art? Communicative Disorders Review, 2007; 1, 51.

8. Sataloff RT. Professional voice. San Diego: Plural Publishing Inc., 2005.

9. Boone DR. Is your voice telling on you? How to find and use your natural voice. London: Whurr Publishers Ltd., 1997.

10. Sabol JW, Lee L, Stemple JC. The value of vocal function exercises in the practice regimen of singer. J Voice, 1995; 9(1): 27-36.

11. Tay EYL, Phyland DJ, Oates J. The effect of vocal function exercises on the voices of aging community choral singers. J Voice, 2012; 26(5): 672.e19-27.

12. Sauder C, Roy N, Tanner K, Daniel R. Houtz, Smith ME. Vocal function exercises for presbylaryngis: A multidimensional assessment of treatment outcomes. Ann Otol Rhinol Laryngol, 2010; 119(7): 460-67.

13. Desai V, Mishra P. Voice therapy outcome in puberphonia. J Voice, 2012; 2(1): 26-29.
14. Fu S, Theodoros DG, Ward EC. Delivery of intensive voice therapy for vocal fold nodules via telepractice: a pilot feasibility and efficacy study. J Voice, 2015; 29(6): 696-706.

15. Fu S. Efficacy of intensive voice therapy for patients with vocal fold nodules. 2015, espace.library.uq.edu.au/view/UQ:371377.

16. Pimenta RA, Dájer ME, Hachiya A, Cordeiro GF, Tsuji DH, Montagnoli AN. High-speed kymography identifies the immediate effects of voiced vibration in healthy vocal folds. Int Arch Otorhinolaryngol, 2013; 17(1): 74-79.

17. Domańska M. Ocena skuteczności terapii głosowej w leczeniu zaburzeń głosu u nauczycieli. Medycyna Pracy, 2003; 4: $319-25$.

18. Zigler A, Amanda I, Gillespie AI, Verdolini Abbott K. Behavioral treatment of voice disorders in teachers. Folia Phoniatr Logop, 2010; 62: 9-23.

19. McCullough GH, Zraick RI, Balou S, Pickett HC, Rangarathnam B, Tulunay-Ugur OE. Treatment of laryngeal hyperfunction with flow phonation: A pilot study. J Voice, 2012; 2(2): 64-69.

20. Anhaia TC, Gurgel LG, VieiraRH, Cassol M. Direct and indirect vocal interventions for teachers: a systematic review of the literature. Audiol, Commun Res, 2013; 18(4): 363-68.

21. Roy N, Gray SD, Simon M, Dove H, Corbin-Lewis K, Stemple JC. An evaluation of the effects of two treatment approaches for teachers with voice disorders: A prospective randomized clinical trial. J Speech Lang Hear Res, 2001; 44: 286-96.

22. Malki KH, Nasser NH, Hassan SM, Farahat M. Accent method of voice therapy for treatment of severe muscle tension dysphonia. Saudi Med J, 2008; 29(4): 610-13.

23. Chen SH, Hsiao TY, Hsiao LC, Chung YM, Chiang SC. Outcome of resonant voice therapy for female teachers with voice disorders: perceptual, physiological, acoustic, aerodynamic, and functional measurements. J Voice, 2007; 21(4): 415-25.

24. Stemple JC, Lee L, D’Amico B, Pickup B. Efficacy of vocal function exercises as a method of improving voice production. J Voice, 1994; 8(3): 271-78.

25. Varma A, Agrahari AK, Kumar R, Kumar V. Role of therapy in patients with mutational falsetto. IJOPL, 2015; 5(1): 25-27. 
26. Bassiouny S. Efficacy of Accent Method of voice therapy. Folia Phoniatr Logoped, 1998; 50: 146-64.

27. Kotby MN. The Accent Method of voice therapy. San Diego, California: Singular Publishing Group Inc., 1995.
28. Thyme-Frokjaer K, Frokjaer-Jensen B. The Accent Method: A rational voice therapy in theory and practice. Speechmark Publishing, 2001.

29. Kazanecka E, Wrońska A, Szkiełkowska A, Skarżyński H. Zastosowanie Metody Akcentów do rehabilitacji zaburzeń głosu mówionego i śpiewanego. Audiofonologia, 2004; 26: 81-84. 